$$
\text { (v) البحث }
$$

\title{
Using basic Geometric Shapes to Design Toys: an approach to develop Creative Thinking in children
}

Ghada Mustafa Mohammed Rashwan Lecture of Decorative Design in a faculty of Specific

Education Department Art Education

2014 


\section{Using basic Geometric Shapes to Design Toys: an approach to develop Creative Thinking in children}

\section{Introduction}

This research sets out to design toys depends on the basic of geometry (i.e., square, circle and triangle) to develop the creativity of Kindergarten Children.

A "toy" is defined as an object or thing that can be used or manipulated to amuse and encourage playfulness. Reiber, Luke, and Smith (1988) noted that toys as instruments of play make learning fun and more effective especially if the toy is chosen voluntarily, involves active engagement, and is pleasurable(V. Clavio \& C. Fajardo 2008,p88).

Generally, toys consist of convergent and divergent materials. Puzzles, simple card and board games, and sorting and stacking materials are examples of convergent materials found in a typical pre-school classroom. These have different purpose and are generally used in the different way each time. Divergent materials, like blocks and building sets, are toys that lead to multiple uses and are more open-ended, and, thus, encourage divergent or lateral thinking. Divergent thinkers search for many different ways to interpret a problem. They learn to work toward achieving a goal and gain confidence in their ability to reach a solution. The materials that are used in problem solving activities encourage children to explore, provide opportunities to discover simple cause-and-effect relationships, and provide open-ended experiences for choosing and making decisions.

Segatti, Du-Paul, and keyes (2003) have noted that when children innovate with toys, these children are learning to use their thinking skills to solve problems (V. Clavio \& C. Fajardo 2008,p89). Toys using basic geometric shapes can be utilized to develop creative thinking skills in kindergarten children. Basic geometric shapes are regular objects; one can draw one or more lines through them that divide them exactly 
in half such that the two parts are mirror images of each other. Examples of these axes of symmetry are shown in Figure 1.

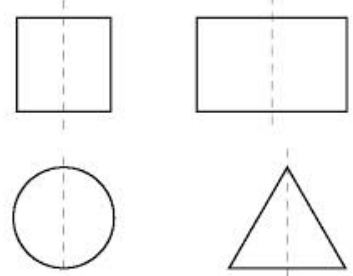

Figure 1: the symmetry of basic design shapes

Play has been strongly featured in many of the discussions on creativity in kindergarten. Therefore, by designing toys based on basic geometric shapes to develop kindergarten children's creativity. These toys will encourage them to use many different strategies, including problem-solving, play strategy, and cooperative play, all of which aim to enhance divergent thinking in the child.

This project had 2 phases. Phase 1 involved the analysis of kindergarten children's abilities and the importance of design toys to encourage them to think in a creative manner by using geometric shapes. Phase 2 involved the practical experience of putting these toys to use.

The role plays in the development of creative thinking in kindergarten

The stages of child development differ from one another, but every child grows steadily through each stage. Moreover, for every stage of childhood, the characteristics and attributes of play are different from the previous and the following phases' play.

Early childhood (birth to six years) is divided into: infancy (from birth to two years), the nursery stage (from two to three years), and kindergarten (from three to six years)(sedki 2001, p13). Generally, children in kindergarten: 
- Are aware of the world around them, and follow a routine of "follow up, monitoring and observation".

- Prefer play that is simple and uncomplicated.

- Develop play develops while becoming four- to talk and explore.

- Begin collective play.

- Care about rules in games and imagine toys.

A series of studies carried out by several researchers, such as J. Piaget and Perry, have shown that play as a means of improving thinking skills in children under the age of six is not limited to its impact on motor skills. Rather, the cognitive, emotional, and social aspects of play contribute to the child's mental development. Play broadens the stimulation encountered and activates memory, giving them the capacity to imagine, as confirmed in a study by Torrance (1970) on the critical importance of games based on problem-solving. Moreover, the educational value of these games increases if they are based on conscious planning and a methodology with clear goals (www.hikmehschool.com).

The Encyclopedia of modern methods of learning offers several strategies for education at this stage, including: discovery learning and learning to play, which includes the development of creative thinking strategies (discovery and problem solving skills).

The strategy of learning to play can give a3 to 6-years-old child (i.e., the children who are the focus of this study) a chance to solve problems, either consciously or unconsciously, which often cannot be expressed. Children must play a way out of the problem, thus learning to resolve the problematic positions that may lead to frustration in their daily lives. Learning to play also satisfies the child's physical, psychological, and social development needs through the games they use. (www.moeforum.net/vb1/attahment.php). 
This study focuses on games of construction and installation. Joining and merging elements helps the child to link the parts to each other and begin to execute simple tasks. This then extends to work that requires some creative thinking.

\section{CHILDHOOD GAMES IN KINDERGARTEN (FROM THREE TO SIX YEARS)}

Preschool children express feelings and emotions through play. They can also develop social skills and communication through games that require mental imagination, thinking, and visual perception. Robin Kenneth has classified children's systems of play behavior into the following categories:

1- Motion play, including models and activities.

2- Construction playing, such as mechanical hand games.

3- Symbolic, "representative" play.

4- Games with rules.

During the kindergarten phase, the fourth category includes several different types of games. These include:

- Games that develop motion activities

- Games that develop art and music skills

- Games of construction and installation

- Games that involve configuration solution

- Games with rules

- Cognitive games

- Jigsaws

- Imaginary games.

This research examines games based on the skills of merging, integration construction, and installation that develop the child's abilities in innovation and creativity. Games designed based on geometric shapes have multiple 
solutions and help develop creative thinking. To design such games, careful planning and the development of a scientific methodology with clear objectives is necessary to achieve the desired benefits for the child. Proper planning ensures the identification of games that work on the development of aspects of the child's personality and mental, emotional, and social skills.

Games of construction and installation are synthetic games. Synthetic games train children to configure things stereoscopically, through which they gain a certain amount of self-confidence and develop aesthetic and technical tastes. These games are useful in kindergarten programs for children to acquire skill and precision in installation, classification, composition, and construction. The development of these skills leads to more flexible eye-hand coordination, followed by more exact fingertip skills. An example of such a game is shown in Figure 2 (Ali 2004, p233).

Construction cubes, or building blocks, shown in Figure 3, are wooden cubes used in various ways in construction. For instance, they allow children to build houses, fences, and castles. Construction and installation games involving building blocks can also be made of plastic or include model furniture (e.g., tables and chair, etc.). Assisting learning and exploration through both individual and collective games(Osman1995, p63), games like Dado cubes in Figure 4, synthetic games like "Micano" engineering cubes in Figure 5, and wooden cubes raise the child's affinity for installation and construction, which encourages creativity and through which they gain manual dexterity and improved cognition(Ali 2004", p237). 


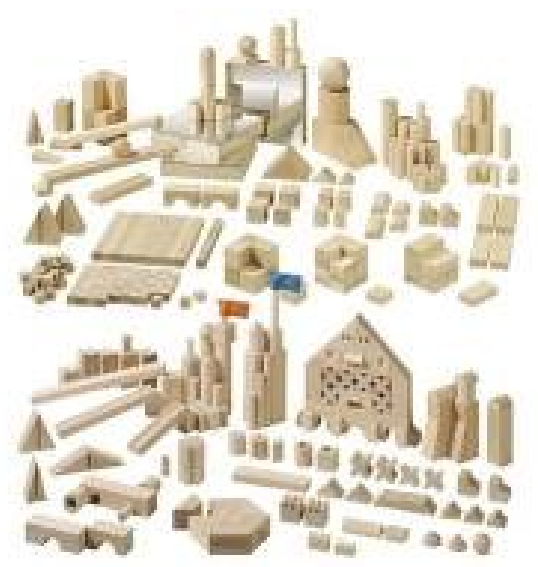

Figure2. Construction Cubes Block

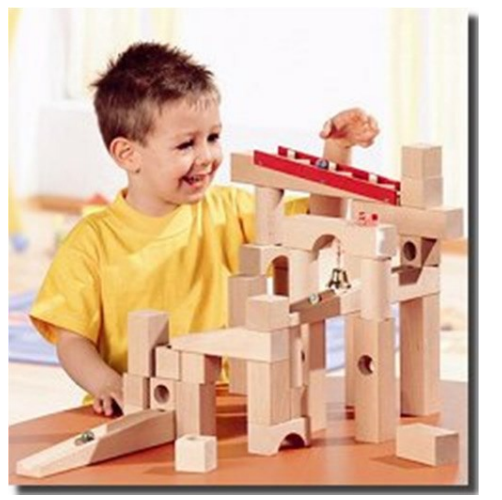

Figure3: wooden blocks used in various ways in construction

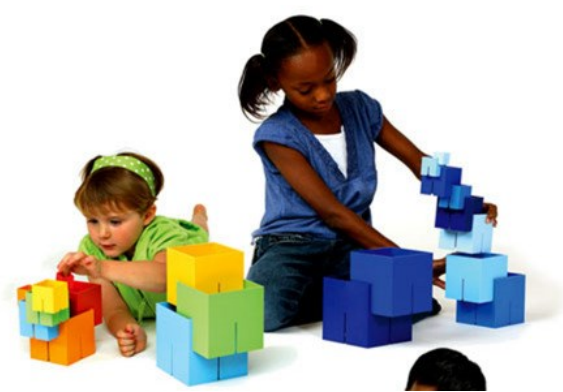

Figure 4: Dado cubes 


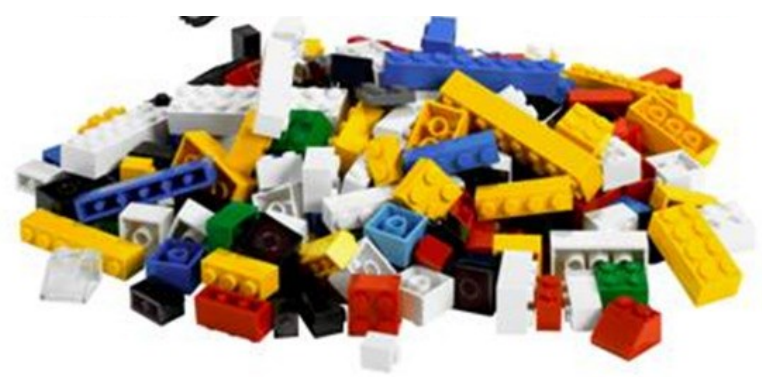

Figure 5: "Micano" engineering cubes

Games that involve configuration solution include games and puzzles. Figures 6 show sets of puzzle games.

Figure 6: set of puzzle games

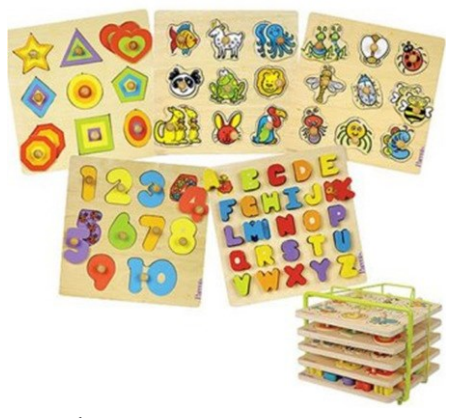

As instructional tools, games are effective. Furthermore; they provide insight for early childhood advocates who wish to explore the many possibilities of toys as instructional tools. Puzzles are toys that encourage children to think of ways to put the pieces together. Children manipulate the pieces while making sense of how they work. Puzzles encourage children to construct their own learning.

Through the use of strategic games, children learn to apply their logic, critical thinking, and creative problem-solving skills to form successful game-winning strategies.

Creativity is an important human characteristic. It is perhaps best thought of as a process, requiring a mixture of ingredients, including personality traits, abilities and skills. 
Early years staff can help young children to develop their creativity by providing a creative environment, helping children to build up their skills through play, encourage behaving creatively, and praising children's creative efforts (Moran 2004, p9).

Most theorists agree that the creative process involves a number of components, most commonly imagination and originality. We can develop creative thinking in children by providing:

1- An appropriate environment for play and discovery, freedom of thought, and playing games through several innovative.

2- A chance to discover solutions and their full potential without providing turnkey solutions because this kills their ability to think and come up with new solutions.

3- An opportunity for challenge, adventure, and imagination through games that help them develop an innovative spirit and their own puzzles.

Both creativity and play require imagination, insight, and problem-solving. The encouragement of children's play is fundamental to the formation of a creative environment.

Creative thinking of the most important educational goal sought by developed countries, since this contributes to scientific progress and economic prosperity in the modern era. While creativity and attention to the creative are important for industrially developed communities, these should also be increasingly important in developing countries. Educational and psychological studies have shown that creativity is a process that requires learners to problem-solve. This means that they must work to perceive gaps, search for information, and build hypotheses, test hypotheses, and link results. Thus, the individual must possess the specific features Guilford has mentioned as the three most important attributes that must be available in the mentality of the creative person: fluency, 
flexibility, and originality. With this, the learner is able to produce the most fluent, intellectual, and flexibility automatic response to the problem or situation, include varied and unusual possibilities. Creative thinking depends on the production of something new or out of the ordinary. To have a novel, authentic original, it is imperative that there must be a creative environment to aid in creative processing of results and in experimenting. The environment must encourage the exchange and development of ideas. Societies that allow for creative thinking, such as the Japanese, rely on seriousness, order, intensive effort, and training to solve problems since children begin kindergarten (http://www.abegs.org). This is the aim of the current research, to "design games for children to develop their creative thinking by using basic geometric shapes: triangle, square, and circle".

The creative thinking process involves four steps: analysis, brainstorming, break it down \&review (http://alliesconsulting.com/downloads/creative-thinking.pdf). Explaining how these are related to games and play.

Step1 is analysis. Begining by looking over the game .you should know every thing about instructions setting details and asking questions. You must get to know the aim of the same.

Step 2 is brainstorming. This is the true area of creative thinking. Once you know about the instructions of the game, you can begin to start thinking. You can brainstorm in any way that works for you. Whatever works for you is the best.

Step 3 is to break it down. Now that you have a nice collection of ideas, you can start going through them and weeding out ones that will not work. You should end up with the ideas that seem to be the best solutions.

Step 4 is review. The final step involves getting your solution. This will help you to come up with one or two ideas that seem to stand out and be the best ideas.

Kindergarten is an important stage for children to increase their creative thinking. Because play is everything in their lives, especially at this stage, this study will depend on games 
designed with the aim of increasing creativity in children through the use of simple shapes (triangles, squares, and circles).

Since the nineteenth century, educators interested in childrearing have used geometric patterns. Some scientists analyzed the visual experience of simple repetitive and stereoscopic elements, such as squares, triangles, and circles and their holograms.

Work in the field of art education has shown that educators can design games that help deliver some of the concepts that help children with innovative thinking through these simple shapes.

Geometric shapes are the starting point for rational concepts such as measurement, proportionality, comparison, and relationships (verstockt 1988, p87).

They are divided into three types: regular, semi-regular, and non-regular forms. Regular forms are characterized by having more uniform and symmetrical elements around the center, like squares, equilateral triangles, and circles. These are called basic geometric shapes, shown in Figure 1, or preliminary spaces. Elementary shapes are the three forms that constitute the foundation of simple geometric networks and are used as models in construction. They are found repeated in many engineering designs and decorations in various civilizations.

There is a relationship between the primary geometric shapes each other clear as follows: Then association between the square and the triangle is that the square is the product of two triangles joined at the center. The relationship between the triangle and the circle is that if one makes straight lines through the center of the circle, as is common as the basis of much early preliminary engineering, then the relationship between the square and circle can also be established through the same points, as illustrated in Figure 7. The relationship between three basic geometric shapes in that all of them can be extracted from the other two forms, as seen in Figure 8 . 
The current study addresses these geometric shapes' use for the development of creative thinking in kindergarten children.
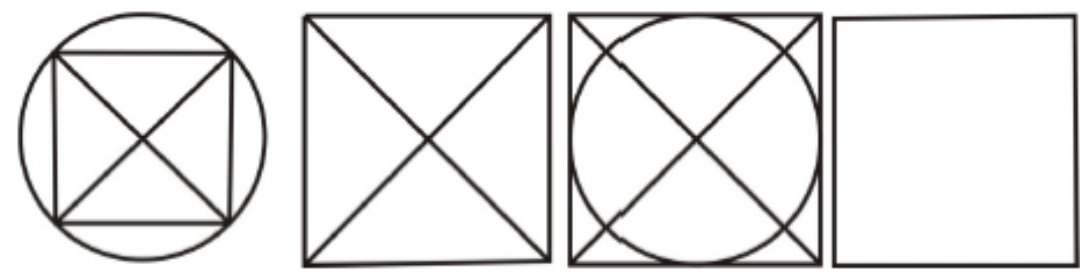

Figure 7: the relationship between the square and the circle is in the union of their centers
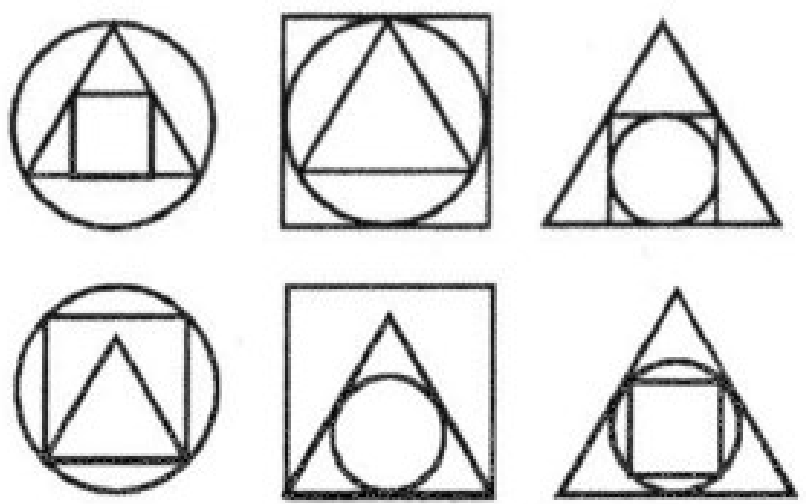

Figure 8 The relationship between three basic geometric shapes extracted from the other two forms

\section{Games designed based on the basic geometric shapes for kindergarteners \\ The previous section discussed the role of toys and play in the development of children's creative thinking, as confirmed by research on games. This development depends on two skills: a) combine and merge, and b) construction and installation. In such games, because of their active role, children learn through observation, discovery, analysis, organization, classification, and having to think of ways to resolve problems, among other activities.}


It has been found that play is a type of "educational" teaching aid. It is advocated by many scientists and educators because of its important role in the mental, emotional, and social development of children and in their development of creative thinking skills.

The study confirmed that the games based on geometric shapes help children to adjust relationships between the elements of the game, as they allow a wide range of variations and acceptable solutions. These solutions and formulations are sophisticated and they help children access a variety of creative horizons. It is important to note that many education scientists, like Frobel and Montessori, have adopted geometric shapes in the games they provide for child development.

Children do benefit from free play and unstructured art activities. However, left entirely to their own devices, children's play and artwork can become routine and repetitive (Moran 2004, p9). They need stimulation and creative problems to solve.

Designers can help children to develop their creative skills through play by designing toys.

The realization of play in physical dimensions through toys takes a certain amount of design planning if it is to fulfill its role in the development of creative thinking. Some of the design aspects include:

1- Design elements. These are the plastic elements, such as point, line, shape, size, light and shadow, color, space, and body shape.

2- Structure design configuration. This is a system of logo designs. Each work of art is different from the others. The system is based on the organization of these elements

3- Structural foundations of design. These are the foundations of building design and include a range of methods, including: shaping and changing the space, 
using shape and different textures, colorimetric consensus, using shape and contrast, exchanging figure and ground, repeated elements, adjacency relationships, and overlap between shapes (Shawki2005, p139). In the foundations of design, the main aesthetic objectives are rhythm, balance, unity, redundancy, diversity, sustainability, proportionality, and sovereignty.

Children are attracted to visual methods, so it is important to find materials and various tools that can be modified for interaction without verbal methods. Visible designs are the best style for children's education, as this communicates information in an easy and simple way.

The manual and technical areas are the primary point of entry for children's sensory training. These skills are:

- Combine and merge

- Coloring.

- Construction and installation.

- Planning.

In the practical conducted, basic geometric shapes were basic in the design of games for aim to develop creative thinking through the successful application of design elements and foundations. This relationship requires the juxtaposition of units and elements to achieve a design based on poise and rhythm.

The research experience was created such that it would deliver design concepts of related elements and foundations of design. To that end, the games designed were based on getting the child to form flat body holograms of the shapes, to describe their characteristics, and to see how to combine them by analyzing the shapes. Through this process, the children would realize the relationship between the parts of the game, reformat, disassemble, and install. 


\section{Application}

The application of this research was based on previous studies on the forms of basic engineering and their role in designing games to help develop creative thinking in children. It was understood that play activities performed by children since birth depend on the characteristics of the stage of development of each child, where the play takes place, and the tools used to help achieve their goals.

The design was an attempt to represent the aesthetic foundations of the design objective. Reflecting the aesthetic purpose and the functional work design. (Shawki 1988, p5).

Based on my findings, is clear that children like geometric patterns and they tend to choose toys based on these. Games are an important part of a child's life. They affect behavior and help them grow in several areas. So we must choose games for children wisely. It is the role of the designer to achieve the general objectives for each game.

In the research experiment with the designed games, the idea of the games is to deliver design concepts such as size and color. The figure in the game included deletion, addition, and repetition to achieve the design foundations of both poise, symmetric or asymmetric, and rhythm, which is the result of harmony between the elements of the game.

The components of the experiment included elements and tools. The elements of the experiment included the square, the circle, and the triangle as flat geometric shapes. Through this definition, the child will come to understand the design elements of the line, color, space, and size during the design operations, which include repetition, deletion, and addition. The tools I used in the experiment included wood grain and colorful plastic.

Regarding the design elements, I relied on connecting design concepts such as line (color, thickness, and direction), space, size, and vacuum.

Through the structural systems, we find the relationship between figures and ground and the axes upon which the 
system is designed. The structural foundations addressed are unity, rhythm (regular or irregular), proportionality, and sovereignty. The design processes included deletion, addition, repetition through minimization and maximization, relations juxtaposition, and contactless relations.

In terms of the limited, I identified the forms of square, triangle, and circle in the experiment as regular geometric shapes characterized by a diverse array of geometric vocabulary that can be invested into the design of games.

The variables of the experiment were based on changing the experience by changing design elements; which also depended on the vocabulary of the form.

The experiment included three phases, which I will discuss as Group A, Group B, and Group C. Group A included flat-design games with plastic variables that varied in color, space, or line. This shows up in every game design element because I sought to attract the child, to include the possibility of overlap, and to show juxtaposition- searchrepetition relationships to help develop creative thinking through the variety of solutions that may occur to the child. Group B included stereoscopic game designs, which varied in color, space, and size. These games also include spaces and various bodies made up of movable cubes. In Group C, the games had a combined design of both flat form and threedimensional bodies. 


\section{Group A: DESIGN FLAT GAMES:}

Table 1. Game no.1 color pattern square (figure 9)

\begin{tabular}{c|l}
\hline $\begin{array}{c}\text { Goal of the } \\
\text { game }\end{array}$ & $\begin{array}{l}\text { Develop creatively thinking abilities through } \\
\text { access to multiple solutions in the area of specific } \\
\text { shape or non-specific known player on the basis of } \\
\text { symmetric and non-symmetric design equilibrium. }\end{array}$ \\
\hline Material & wood \\
\hline $\begin{array}{c}\text { Number of } \\
\text { players }\end{array}$ & one \\
$\begin{array}{c}\text { Explanatio } \\
\text { of the game }\end{array}$ & $\begin{array}{l}\text { The game consists of nine color boxes of adjacent } \\
\text { squares that produce decorative designs through } \\
\text { the repetition of units in different positions to } \\
\text { reach creative solutions based on different shapes } \\
\text { and colors. }\end{array}$ \\
\hline $\begin{array}{c}\text { Rules of } \\
\text { the game }\end{array}$ & $\begin{array}{l}\text { The child adjoins squares in different } \\
\text { configurations }\end{array}$ \\
\hline Dimension & $\begin{array}{l}\text { Square cards } 5 \times 5 \text { cm, which accumulate; the } \\
\text { units are produced within a square space of } 15 \times 15 \\
\text { cm }\end{array}$ \\
\hline $\begin{array}{c}\text { Analysis } \\
\text { logos design }\end{array}$ & $\begin{array}{l}\text { The game is meant to deliver the design concepts } \\
\text { of space and color through the juxtaposition of } \\
\text { square cards, design iteration, juxtaposition, and } \\
\text { exchange between figure and ground. }\end{array}$ \\
\hline
\end{tabular}




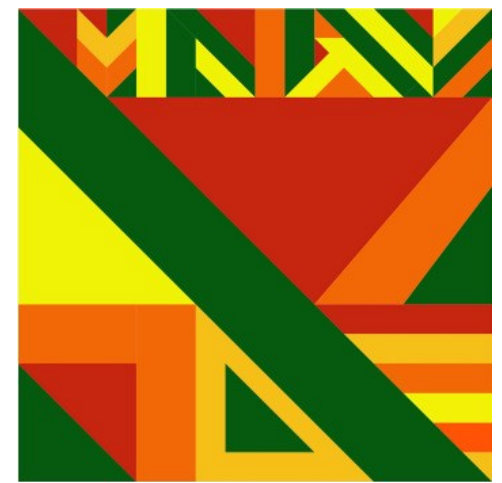

Figure 9. Game no.2 color pattern square, square Cards are $5 \times 5 \mathrm{~cm}$ repeat inside a $15 . \mathrm{cm}$ square 
Table 2. Game no.2 puzzle square (figure 10)

\begin{tabular}{|c|c|}
\hline $\begin{array}{l}\text { Goal of the } \\
\text { game }\end{array}$ & $\begin{array}{l}\text { Develop child's ability to think creatively in } \\
\text { cooperative play and to define geometric shapes. }\end{array}$ \\
\hline Material & Wood colored acrylic colors \\
\hline $\begin{array}{l}\text { Number of } \\
\text { players }\end{array}$ & one or more \\
\hline $\begin{array}{l}\text { Explanatio } \\
\mathrm{n} \text { of the game }\end{array}$ & $\begin{array}{l}\text { The game is composed of } 56 \text { pieces colored green, } \\
\text { Blue, Orange, and purple. } \\
\text { The parts are joined to form a box with a specific } \\
\text { area of } 20 \times 20 \mathrm{~cm} \text {. The child may play alone or } \\
\text { involve a partner by taking turns in the } \\
\text { development of the parts in the area until its shape } \\
\text { is as finished as it can be. The way it comes out in } \\
\text { the selected area includes many different } \\
\text { decorative designs! which vary depending on the } \\
\text { child's creativity and thinking }\end{array}$ \\
\hline the $\begin{array}{l}\text { Rules } \\
\text { game }\end{array}$ & $\begin{array}{l}\text { This game is played by one or more children and } \\
\text { is limited by a time of } 10 \text { minutes to form a } \\
\text { decorative box or units. }\end{array}$ \\
\hline s Dimension & Square area of $20 \times 20 \mathrm{~cm}$. \\
\hline $\begin{array}{c}\text { Analysis } \\
\text { logos design }\end{array}$ & $\begin{array}{l}\text { The game depends on the shape of the square and } \\
\text { analyzes the geometric axes of horizontal, } \\
\text { Vertical, and diagonal. Triangles appear, as does } \\
\text { the circle. The square is divided into four squares, } \\
\text { repeated in a symmetric manner. } \\
\text { The game relies on colors: green, orange, blue, } \\
\text { and purple. These opposite and complementary } \\
\text { colors help confirm the value of the color. A } \\
\text { symmetrical poise is achieved between the parts of } \\
\text { the box. }\end{array}$ \\
\hline
\end{tabular}




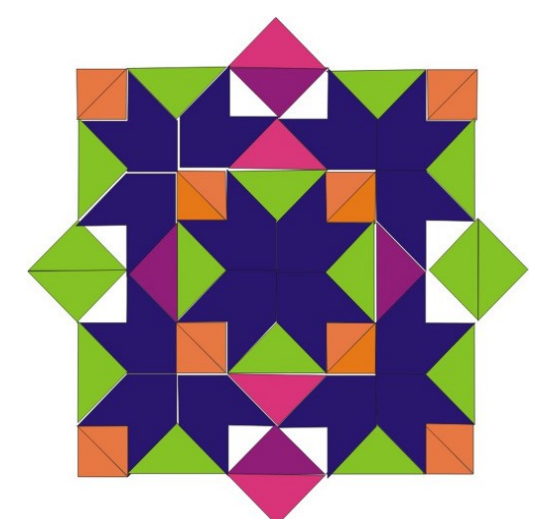

Figure 10. Game no. 2 puzzles square, square area of $20 \mathrm{x}$ $20 \mathrm{~cm}$.

\section{GROUP B: POLYPHONIC GAMES DESIGN BASED ON CUBIC DESIGNS}

Table 3. Game no. 1 puzzle cubes (figure 11)

\begin{tabular}{c|l}
$\begin{array}{c}\text { Goal of the } \\
\text { game }\end{array}$ & $\begin{array}{l}\text { Development of creative thinking and educating } \\
\text { the child on area, mass, and color }\end{array}$ \\
\hline Material & Stained wood. \\
\hline $\begin{array}{c}\text { Number of } \\
\text { players }\end{array}$ & one \\
$\begin{array}{c}\text { Explanation } \\
\text { of the game }\end{array}$ & $\begin{array}{l}\text { The game consists of eight cubes, with each } \\
\text { painted with different color spaces than the } \\
\text { others. The player installs cubes in the geometric } \\
\text { configurations of the circle, triangle, and square. } \\
\text { The reciprocal relationships between figure and } \\
\text { ground depend on the player's choices in } \\
\text { arranging the cubes on top of each other. }\end{array}$ \\
\hline $\begin{array}{c}\text { Rules of the } \\
\text { game }\end{array}$ & $\begin{array}{l}\text { The child must install the cubes in different } \\
\text { configurations }\end{array}$ \\
\hline Dimensions & $\begin{array}{l}\text { The game consists of eight cubes with cubic } \\
\text { dimensions of } 4 \mathrm{x} 4 \mathrm{x} 4 \mathrm{~cm}\end{array}$ \\
\hline $\begin{array}{c}\text { Analysis } \\
\text { logos design }\end{array}$ & $\begin{array}{l}\text { This game design relied on the personal } \\
\text { realization of the concepts of cube and mass }\end{array}$
\end{tabular}


distribution among color spaces for the child to define geometric spaces. The player creates color spaces of the colors of choice. These are balanced and diverse in design space. The game also includes methods of construction, which are utilized in the juxtaposition and overlapping of cubes.
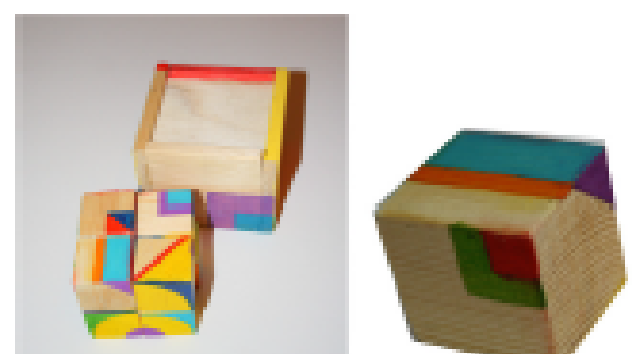

Figure 11. Game no.1puzzle cube, The game consists of 8 cubes with cubic dimensions of $4 \times 4 \times 4 \mathrm{~cm}$ each.

Table 4. Game no.2 puzzle cubes (figure 12)

\begin{tabular}{c|l}
\hline $\begin{array}{c}\text { Goal of the } \\
\text { game }\end{array}$ & $\begin{array}{l}\text { Development of divergent thinking, to identify } \\
\text { space and color. }\end{array}$ \\
\hline $\begin{array}{c}\text { Material } \\
\text { players }\end{array}$ & Mixed Acrylic \\
\hline $\begin{array}{c}\text { Explanatio } \\
\text { of the game }\end{array}$ & $\begin{array}{l}\text { The game consists of 21 cubic vacuum ranging } \\
\text { from small to large, distributed in 16 cubic cubes } \\
\text { with a red frame color, four cubes framed in blue, } \\
\text { and one cube framed in white. The player arranges } \\
\text { cubes and their distribution. }\end{array}$ \\
\hline $\begin{array}{c}\text { Rules of } \\
\text { the game }\end{array}$ & $\begin{array}{l}\text { The player distributes innovative designs with } \\
\text { cubes. formations depend on the gradient sizes and } \\
\text { the choice of colors. }\end{array}$ \\
\hline Dimension & $\begin{array}{l}16 \text { cubic } 2 \times 2,4 \text { cubes } 4 \times 4, \text { and one cubic } 6 \times 6 . \\
\mathrm{s}\end{array}$
\end{tabular}




\begin{tabular}{c|l}
\hline Analysis & $\begin{array}{l}\text { The game depends on the cube as stereoscopic, } \\
\text { giving the body a sense of emptiness and mass. } \\
\text { The game relies on basic colors, such as red- and } \\
\text { blue frame cubes, to emphasize the value of color. } \\
\text { The gradient size of the cubes helps create } \\
\text { diversity. }\end{array}$
\end{tabular}

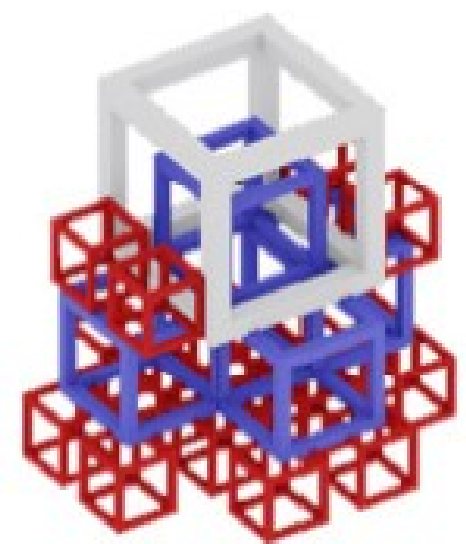

Figure 12. Game no. 2 puzzle cubes, sixteen cubes of 2 $\mathrm{cm}$, four cubes of $4 \mathrm{~cm}$, and one cube of $6 \mathrm{~cm}$.

\section{GROUP C: DESIGN COMBINE FORM FLAT AND THREE DIMENSIONAL BODY}

Table 5. Game no.1 flat board square and cubes (figure 13)

\begin{tabular}{c|l}
\hline $\begin{array}{c}\text { Goal of the } \\
\text { game }\end{array}$ & Develop a child's ability to think creatively. \\
\hline $\begin{array}{c}\text { Material } \\
\text { players }\end{array}$ & Wood painted in acrylic colors. \\
\hline $\begin{array}{c}\text { Explanatio } \\
\text { of the game }\end{array}$ & $\begin{array}{l}\text { The game is composed of a square board divided } \\
\text { into squares painted with engineering units. It } \\
\text { simply relies on a geometric analysis of the unity } \\
\text { of the square. It also consists of four cubes of } 4 \times \\
4 \times 4 \text { cm. There are similar charges on the surfaces } \\
\text { of the cube objects cube and on the square plate } \\
\text {.The game also consists of eight } 4 \times 4 \times 4 \mathrm{~cm}\end{array}$ \\
\hline
\end{tabular}




\begin{tabular}{c|l}
\hline Rules of & cubes. \\
the game & $\begin{array}{l}\text { The player exchanges fee aspects of the cube with } \\
\text { fees on small squares in the painting. The player } \\
\text { must put the big cubes in place and then arrange } \\
\text { the small cubes to help balance out different } \\
\text { designs. }\end{array}$ \\
\hline Dimension & $\begin{array}{l}\text { Four cubes of } 8 \mathrm{~cm} \text {, eight cubes of } 4 \mathrm{~cm} \text { on } 24-\mathrm{cm} \\
\text { board }\end{array}$ \\
\hline Analysis & $\begin{array}{l}\text { The game depends upon relationships between and } \\
\text { juxtaposition of the cubes on the floor of the } \\
\text { square. The relationship between the three } \\
\text { dimensional (cube) and flat shape (box) highlights } \\
\text { the ability of each to achieve equilibrium and } \\
\text { stability in the design. }\end{array}$ \\
\end{tabular}

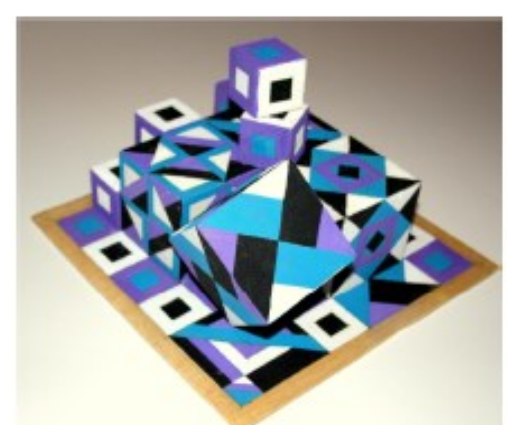

Figure 13. Game no.1 flat, Square board and cubes, four cubes of $8 \mathrm{~cm}$, eight cubes of $4 \mathrm{~cm}$ on $24 \mathrm{~cm}$ board.

Table 6. Game no.2 shapes and forms (figure 14)

\begin{tabular}{c|l}
\hline $\begin{array}{c}\text { Goal of the } \\
\text { game }\end{array}$ & $\begin{array}{l}\text { Development of a child's ability to think creatively } \\
\text { to identify three-dimensional bodies and relating } \\
\text { elements of the cube with flat geometric spaces. }\end{array}$ \\
\hline Material & Wood colored acrylic colors. \\
\hline $\begin{array}{c}\text { Number of } \\
\text { players }\end{array}$ & One or more \\
\hline Explanatio & The game is composed of 24 square that overlap \\
\hline
\end{tabular}




\begin{tabular}{|c|c|}
\hline $\mathrm{n}$ the game & $\begin{array}{l}\text { each other to create the space shown in Figure } 14 \text {. } \\
\text { This is a ground game, which the child may have } \\
\text { to deal with as a flat object and then switch to the } \\
\text { boxes for the output. The decorative engineering } \\
\text { units rely on black and white, which is handled by } \\
\text { the child as a stereoscopic. Every six squares } \\
\text { would be a cube. }\end{array}$ \\
\hline $\begin{array}{lr}\text { Rules of } \\
\text { the }\end{array}$ & $\begin{array}{l}\text { The child must address the fact that squares make } \\
\text { up stereoscopic bodies through the installation of } \\
\text { flat shapes or through combining flat-form and } \\
\text { three-dimensional bodies by thinking creatively. }\end{array}$ \\
\hline Dimension & $24 \mathrm{~cm}$ square area, with each square at $6 \times 6 \mathrm{~cm}$ \\
\hline $\begin{array}{c}\text { Analysis } \\
\text { logos design }\end{array}$ & $\begin{array}{l}\text { The game depends on the relationship between the } \\
\text { flat shapes and three dimensional bodies. The } \\
\text { game relies on individual cubes. The engineering, } \\
\text { which consists of six boxes for each square, is } \\
\text { divided into colored triangles, alternating between } \\
\text { black, white, and gray. When juxtaposed squares } \\
\text { consist of color boxes, the colors vary according to } \\
\text { the order of the boxes. }\end{array}$ \\
\hline
\end{tabular}

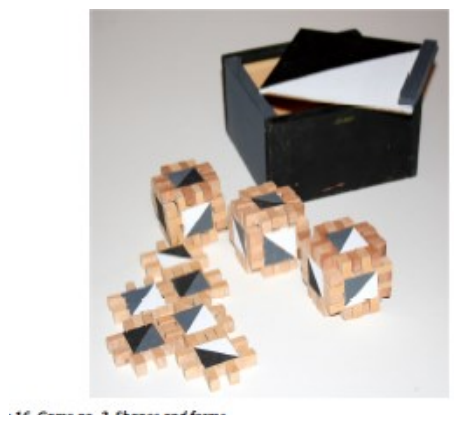

Figure 14. Game no.2 shapes and forms 


\section{Conclusion}

Children from three to six years of age like geometric games, which depend upon the skills of, integration, construction, and installation.

There is a link between the goals of art education and the goals of playing in that both help children develop creative thinking through the provision of materials and tools to help children learn to innovate. So we as an educational designer can contribute the child to realize design logos dimensions by offering games that implement design concepts through design elements that the child can access through design processes, such as seeking the structural foundations of poise and rhythm of the game.

Design elements play a role in the design of the game through the lines, spaces, colors, and textures. These can achieve educational that goals lead to the development of the child's creative thinking through the formation of new and different decorative styles.

Playing means education aimed at developing innovation in children. Play activity, both recreational and educational, helps children develop emotionally, physically, socially, and mentally. It also helps the development of creative thinking by offering multiple solutions, which can help the child to think in a way that will lead to problem- solving and discovery.

\section{References}

- Abdel Fattah, Manal. 2005. The basic skills of visual arts for kindergarten children. Cairo: Library Zahra East.

- Sedki, Saria.2001.Arab standards and \&play value for children. Egypt: The Department of Family, Women and Children Affairs of the Secretariat of the League English. 
- Ali, Negm Aldin. 2004. Psychology play. Kuwait: Farmer Library. Arab Bureau of Education for the Gulf States . http://www.abegs.org.

- Clavio, Josefa Carina V., and Amelia C.Fajardo. 2008. "Toys as instructional tools in developing problem-solving skills in children". Education Quarterly 66(1): 87-100 \{Cited September 15, 2012\}. Available from http://journals.upd.edu.ph/index.php/edq/article/view/1566

- Moran, James D. Autumn 2004. Developing young children's creativity \{cited September 15, 2012\}.Available from

http://www.nfer.ac.uk/nfer/publications/55502/55502.pdf

- Osman, Farouk. 1995. The psychology of playing and learning. Cairo: Knowledge House.

- Pronin, Doris.1998. Play from birth to twelve and beyond. New York and London: Garland publisher.

- Segatti. Laura, Judy Brown Du Paul, and Tracy Keys. 2003. "Using everyday materials to promote problem solving in toddlers". Journal for the national association for the Education of Young Children 58 (5):12 - 18.

- Shawki, Ismail.1998.” Achieving unreal dimension in decorative configuration through the construction of linear and dimensional values for the color", General Authority for Cultural Palaces, December 12.

- shawki, IsmaiL.2005. Design elements and foundations in fine art. Cairo: Library Zahra East.

- Verstockt, Mark.1988. The genesis of form: from chaos to geometry. London: Blond Muller\& White.

- http://www.hikmehschool.com/makalat_a13.htm (website) (cited October 30, 2012)

- www.moeforum.net/vb1/attahment.php

- http://alliesconsulting.com/downloads/creativethinking.pdf. 


\begin{abstract}
Abstract: Art Education is one of the means of education which can design creative games plus solutions to help kindergarten children on the development of his creative thinking and about the roles of special education designer promoting positive trends of the child about games, and encourage creativity through the design of games including basic concepts for the development of awareness of the child respect to through the elements and principles of design. In \&research addressing the geometric basic (triangle, circle square) and its plastic solutions, and vocabulary analytical access to many different forms and possibilities multi-out creative designs by easy way suitable for the capacities of the child which can practice activities that devlope creative thinking, taking into account the characteristics of the age group "stage early Childhood ", a child at this stage is characterized by highly dynamic, and fired my mind, the love of a survey led to experimentation, synthesis, analysis and construction and therefore in need of games suitable to play with them including skills jaw and integration, construction, installation, and the more of these tools varied and attractive inspiring his imagination and filling his basic needs. The research aims to employ the plastic possibilities of basic engineering shapes in designing games for kindergarten children, through the exercise by the child for a range of artistic activities for the development of creative thinking.
\end{abstract}

Key words: Basic Geometric Shapes - Design Toys Kindergarten Children - Creative Thinking 


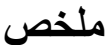

تعد التربية الفنية هى إحدى أساليب التربية والتى بمكن من خلالها تصميم ألعاب تساعد على تتمية التفكير الابداعى عند رياض الأطفال، المصمم التربوى له دور فى تعزيز الاتجاهات الايجابية عند الأطفال نحو الألعاب وتشجيعهم على التفكير بأسلوب ابداعى من خلال تصميم ألعاب تعتمد على أسس وعناصر التصميم، ويتتاول هذا البحث المتغيرات النتكيلية للأشكال الهندسية الأساسية (مثلث، دائرة ومربع) لتصميم ألعاب تتمى التفكير الابداعى عند الأطفال من خلال تحليل المفردات الهندسية والوصول إلى العديد من الأشكال المختلفة بطريقة سهلة ومناسبة لقدرات الطفل ، حيث تتسم تلك المرحلة العمرية بأن الاطفال يستطيعون ممارسة أنشطة تساعد على تتمية تفكيرهم الإبداعي، وهو ذو حركة ديناميكية، يهتم بالتجريب، التوليف، التحليل، والبناء، يميل الى ألعاب تتضمن مهارات منل الفك و التركيب والتى تتسم بالتتوع والجاذبية وتغذي خياله

$$
\text { وتنبع حاجاته وميوله الأساسية. }
$$

يهذف البحث إلى توظيف المتغيرات التشكيلية للأشكال الهندسية الأساسية في تصميم ألعاب تتمي التفكير الإبداعي لرياض الأطفال. 